\title{
Biorational insectoacaricides based on avermectins to protect grapes
}

\author{
Tatiana Dolzhenko ${ }^{1,2^{*}}$, Lyudmila Burkova ${ }^{1,3}$, Oleg Dolzhenko ${ }^{3}$, and Alexander Laptiev ${ }^{1,3}$ \\ ${ }^{1}$ LLC "Innovative Plant Protection Center", Pushkinskaya st., 20, Letter A, pom. 7-N, St. Petersburg - \\ Pushkin-8, P.O. Box 5, 196608, Russia \\ ${ }^{2}$ Federal state budgetary educational institution of higher education "Saint Petersburg state agrarian \\ University", Petersburg highway, 2, St. Petersburg - Pushkin, 196601, Russia \\ ${ }^{3}$ Federal State Budgetary Scientific Institution "All-Russian Scientific Research Institute of Plant \\ Protection", Podbelsky highway, 3, St. Petersburg-Pushkin, 196608, Russia
}

\begin{abstract}
The article presents an assessment of the biological effectiveness of biorational insectoacaricides based on abamectin and emamectin benzoate - metabolites of soil actinomycetes, to protect grapes from pests. We studied the effectiveness of new drugs: Mekar, ME (18 g/l abamectin) and Mabet, EC (18 g/l abamectin) against Schizotetranychus pruni; Yunona, ME (50 g/l emamectin benzoate), Emakleim, VRG (50 g/l emamectin benzoate) and Proclame Fit, WDG (400 g/kg lufenuron $+50 \mathrm{~g} / \mathrm{kg}$ emamectin) against Lobesia botrana in the Krasnodar Region. According to the research results, the drugs Mekar, ME (18 g/l), Yunona, ME (50 g/l) and Proclame Fit, WDG $(400 \mathrm{~g} / \mathrm{kg}+50 \mathrm{~g} / \mathrm{kg})$ are included in the State Catalog of Pesticides and Agrochemicals Permitted for Use on the territory of the Russian Federation and can be used in biologized and adaptively integrated grape protection systems.
\end{abstract}

\section{Introduction}

The most dangerous pests of grapes are the grape moth and mites. Grape moth - Lobesia botrana Den. et Schiff. (Lepidoptera, Tortricidae) polyvoltine species, which in the south of Russia develops in 4 generations, the entire development cycle of which takes place on a grape plant. Grape moth causes direct damage to the crop, damaging the generative organs throughout the seasonal ontogenesis of grapes. Especially serious losses can occur during the mature stage, since various rot intensively develop on clusters damaged by lepidopterous larva. Tetranychidae - sucking pests, feeding on grape leaves, disrupt their photosynthetic activity. Intense damage to the leaf apparatus by mites reduces the adaptive potential of the plant as a whole. Such bushes react more strongly to various environmental stresses. Schizotetranychus pruni (viticola) Oud. (garden (grape) spider mite) - is the dominant and most harmful species in vineyard acarocomplexes $[1,2]$.

With the transition to a highly productive and environmentally friendly agricultural sector, the availability of a sufficient range of biological, biorational and low-toxic chemical means of control of phytophages becomes relevant [3, 4]. Biorational drugs are a

\footnotetext{
"Corresponding author: dolzhenkotv@mail.ru
} 
fundamentally new group of environmentally friendly drugs based on chemical analogues of natural biologically active substances. Increasing attention is paid to their development and application [5]. This is how bioinsecticides and bioacaricides based on synthetic analogs of secondary low molecular weight metabolites of soil actinomycetes, such as avermectins, spinosins and some others, entered the market. These biologically active substances have a number of properties that determine their preferential use in modern biologized pest control programs. They have low toxicity, lack of cumulativeness, and the ability to degrade in the objects of the agroecosystem, which makes it possible not to violate biocenotic relations during their use. Separately, it is worth highlighting such a property of these metabolites as the selectivity of insectoacaricidal action. A variety of chemical groups of these drugs reduces the risk of resistance in target harmful objects $[3,4,5]$.

Avermectins are a complex of chemically related compounds with high biological activity, it includes aversectin $\mathrm{C}$, avertin $\mathrm{N}$, emamectin benzoate abamectin. They are produced by the well-studied soil actinomycete Streptomyces avermitilis M.S.T.D. These metabolites have the unique ability to suppress the development of arthropods by blocking the transmission of electrical impulses in muscles and nerves [6-10]. The mechanism of action of avermectins is based on the stimulation of the influx of chlorine ions, which causes a decrease in the resistance of the cell membrane (depolarization) - such a pathological violation of its functions leads to flaccid paralysis and death of the phytophage [11-15].

The purpose of the research was to identify effective and environmentally friendly insecticides and acaricides for use in integrated control programs for economically significant phytophages of grapes.

\section{Materials and methods}

To assess the biological effectiveness in field screening, bio-rational drugs were selected:

- Mekar, ME - microemulsion (18 g/l abamectin) and Mabet, EC - emulsion concentrate (18 $\mathrm{g} / 1$ abamectin) to control Sch. pruni; - Yunona, ME (50 g/l of emamectin benzoate), Emakleim, WSG - water-soluble granules ( $50 \mathrm{~g} / 1$ of emamectin benzoate) and Proclame Fit, WDG - water-dispersible granules ( $400 \mathrm{~g} / \mathrm{kg}$ of lufenuron $+50 \mathrm{~g} / \mathrm{kg}$ of emamectin) to control L. botrana.

The studies were carried out during the growing seasons of 2017-2019 on industrial vine plantations of the Temryuk district of the Krasnodar Region in accordance with the Guidelines for registration tests of insecticides, acaricides, molluscicides and rodenticides in agriculture (2009).

\section{Results and discussion}

The number of spider garden mites on grapes of Aligote variety reached the threshold by the end of the 2nd decade of July 2018. After the treatment, against the background of an increase in the number of pests for 3 weeks in the control variant (from 19.1 to 34.0 mobile individuals per leaf), in all variants, it decreased to 5.2-7.3 individuals per leaf by 3 -and day; up to 1.73.8 individuals per leaf on the 21 st day $\left(\mathrm{LSD}_{05}=0.7\right)$. On the highly damaged variety Pinot noir of grape, the garden spider mite reached the threshold number earlier than the average long-term period - in the 1st decade of June 2019. The treatment was carried out on June 6. In the control variant, the number of the pest population grew and by the 21 st day it had increased by 3.5 times. The biological effectiveness of the use of drugs Mabet, EC (18 g/l) and Mekar, ME (18 g/l) in two rates of application and in different formulations is presented in Table 1. Both drugs showed a fairly high efficiency in reducing the number of phytophage, close to the efficiency of the standard. At the same time, the effectiveness of the drug in the 
form of a microemulsion slightly exceeded the effectiveness of the drug in the form of an emulsion concentrate.

In 2017, the flight of the first generation of the grape moth of grapes of Muscat Hamburg variety was very extended, with three peaks of abundance with a high amplitude and lasted 47 days - from April 24 to June 9. The largest (third) peak in numbers was 322 individuals per pheromone trap (05.29.17). The conditions for connubium (stable average daily air temperature above $15^{\circ} \mathrm{C}$ ) came after May 13. The first treatment was carried out at the beginning of larva hatching, on May 19. The second - 10 days after the first. The first damage to inflorescences in the control was noted on June 1. Damage in the control reached 0.32 points on the 14 th day after the second treatment $\left(\mathrm{LSD}_{05}=0.01\right)$.

The flight of the second generation was intense and lasted 29 days - from June 18 to July 17. The first hatched larvas were observed in the control on 3-4 July. The first treatment for the second generation of the grape moth was carried out at the beginning of hatching of caterpillars (07/04/17), the second after 10 days. Damage to bunches in the control reached 0.35 points.

Table 1. The effectiveness of the use of drugs Mabet, CE and Mekar, ME on grapes against Schizotetranychus pruni, Temryuk district, Krasnodar Region, 2018-2019.

\begin{tabular}{|c|c|c|c|c|c|c|}
\hline \multirow[t]{2}{*}{$\begin{array}{c}\text { Experiment } \\
\text { variant }\end{array}$} & \multirow{2}{*}{ 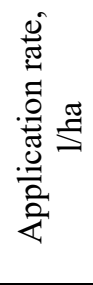 } & \multirow{2}{*}{ 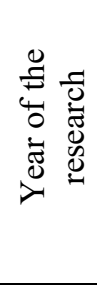 } & \multicolumn{4}{|c|}{$\begin{array}{c}\text { Decrease in the number of spider mites after } \\
\text { treatment in comparison with the initial one, adjusted } \\
\text { for control, } \%\end{array}$} \\
\hline & & & $\begin{array}{c}\text { After } 3 \\
\text { days }\end{array}$ & $\begin{array}{c}\text { After } 7 \\
\text { days }\end{array}$ & $\begin{array}{c}\text { After } 14 \\
\text { days }\end{array}$ & $\begin{array}{c}\text { After } 21 \\
\text { days }\end{array}$ \\
\hline \multirow{2}{*}{$\begin{array}{c}\text { Mekar, ME } \\
(18 \mathrm{~g} / \mathrm{l})\end{array}$} & \multirow{2}{*}{0.75} & 2018 & 68.2 & 83.6 & 90.8 & 92.8 \\
\hline & & 2019 & 81.6 & 82.2 & 79.6 & 79.5 \\
\hline \multirow{2}{*}{$\begin{array}{l}\text { Mabet, EC } \\
(18 \mathrm{~g} / \mathrm{l})\end{array}$} & \multirow{2}{*}{0.75} & 2018 & 62.5 & 74.8 & 89.5 & 89.0 \\
\hline & & 2019 & 80.9 & 66.6 & 73.3 & 73.9 \\
\hline \multirow{2}{*}{$\begin{array}{l}\text { Mekar, ME } \\
(18 \mathrm{~g} / 1)\end{array}$} & \multirow{2}{*}{1.0} & 2018 & 79.1 & 91.0 & 99.6 & 99.1 \\
\hline & & 2019 & 92.6 & 96.3 & 99.5 & 99.0 \\
\hline \multirow{2}{*}{$\begin{array}{c}\text { Mabet, EC } \\
(18 \mathrm{~g} / \mathrm{l})\end{array}$} & \multirow{2}{*}{1.0} & 2018 & 69.4 & 84.8 & 94.9 & 94.3 \\
\hline & & 2019 & 87.8 & 96.3 & 96.2 & 94.2 \\
\hline \multirow{2}{*}{$\begin{array}{l}\text { Vertimek, } \\
\text { EC (18 g/1) } \\
\text { (standard) }\end{array}$} & \multirow{2}{*}{1.0} & 2018 & 69.2 & 89.2 & 97.7 & 97.8 \\
\hline & & 2019 & 87.9 & 99.3 & 98.3 & 99.4 \\
\hline
\end{tabular}

The flight of the third generation began on August 1 and lasted 29 days with three peaks of abundance: the first on August 6-8 (92-121 individuals per trap), the second on August 18 (186 individuals per trap), the third on August 21 (141 individuals per trap). Treatment against the third generation was carried out at the beginning of larva hatching (08.08.17). The first damage to bunches by larva of the third generation in the control was noted late - on the 7 th day after the second treatment $(08 / 25 / 17)$. Starting from the middle of the first decade of August, a high-temperature dry period was observed, only by the middle of the third decade, when the heat began to subside, damage to the bunches began to be noted.

In 2018, the flight of the first generation of the grape moth on the grapes of the varieties Muscat Hamburg and Cabernet Sauvignon began at the end of the second decade of April, earlier than the average long-term data, massive - on April 24. The flight lasted 26 days with two peaks in abundance - 150 individuals per pheromone trap (May 5) and 55 individuals per 
pheromone trap (May 18). The first treatment was carried out at the beginning of larva hatching, on May 10. The second - 10 days after the first. Damage in the control reached 0.98 points on the 14th day after the second treatment $\left(\mathrm{LSD}_{05}=0.03\right)$.

The flight of the second generation of the phytophage was intense and lasted 26 days (June 11 - July 7). The maximum is 40 individuals per pheromone trap. The first treatment for the second generation of the grape moth was carried out at the beginning of hatching of larva (June 16), the second after 10 days. Damage to bunches in the control reached 0.11 points.

The flight of the third generation began on 27 July and was intermittent and low due to drought (5-12 individuals per trap between 9-17 August). The treatment against the third generation were carried out at the beginning of larva hatching (July 31) and after 10 days. Damage to bunches in the control was insignificant.

In 2019, favorable conditions were formed for the development of the grape moth, the beginning of flight was marked on April 30. The first generation flight on grape of Riesling Rhine variety was intense with high peak amplitudes, the highest flight peak was recorded on May 12 (220 butterflies per trap). In comparison with previous years, the flight for this generation was quite compact and amounted to 28 days (until May 27). The flight of the second generation began on June 3-4, was intermittent, of medium intensity and very extended, the maximum flight peak was noted on July 27-30 (39-46 butterflies per trap). The flight of the third generation was moderate and also intermittent; on August 16, the peak of the abundance was 24 butterflies per trap.

Analysis of the results of the experiments showed that the effectiveness of all three insecticides in both rates of application against the grape moth of each generation was quite high and was not inferior to the standard (Table 2).

Table 2. The effectiveness of the use of insecticides on grapes against Lobesia botrana, Temryuk district, Krasnodar region, 2018-2019.

\begin{tabular}{|c|c|c|c|c|c|}
\hline \multirow[t]{2}{*}{ Experiment variant } & \multirow{2}{*}{ 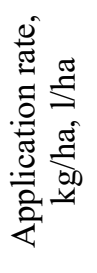 } & \multirow{2}{*}{ 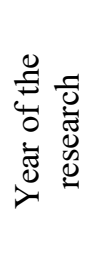 } & \multicolumn{3}{|c|}{$\begin{array}{l}\text { Reduction of damage to bunches by } \\
\text { larvaes after treatment against each } \\
\text { generation, adjusted for control, } \%\end{array}$} \\
\hline & & & I & II & III \\
\hline \multirow{2}{*}{$\begin{array}{c}\text { Emakleim, WSG (50 } \\
\mathrm{g} / \mathrm{kg})\end{array}$} & \multirow{2}{*}{0.3} & 2018 & 88.6 & 91.7 & 92.2 \\
\hline & & 2019 & 96.4 & 95.0 & 82.4 \\
\hline \multirow{2}{*}{$\begin{array}{l}\text { Emakleim, WSG (50 g } \\
\qquad / \mathrm{kg})\end{array}$} & \multirow{2}{*}{0.4} & 2018 & 88.6 & 100 & 100 \\
\hline & & 2019 & 100 & 100 & 88.2 \\
\hline \multirow{2}{*}{ Yunona, ME (50 g/l) } & \multirow{2}{*}{0.3} & 2018 & 95.9 & 100 & 100 \\
\hline & & 2019 & 100 & 100 & 88.2 \\
\hline \multirow{2}{*}{ Yunona, ME (50 g/l) } & \multirow{2}{*}{0.4} & 2018 & 98.0 & 100 & 100 \\
\hline & & 2019 & 100 & 100 & 94.1 \\
\hline \multirow{2}{*}{$\begin{array}{l}\text { Proclame Fit, WDG } \\
(400 \mathrm{~g} / \mathrm{kg}+50 \mathrm{~g} / \mathrm{kg})\end{array}$} & \multirow{2}{*}{0.12} & 2017 & 90.6 & 97.1 & 100 \\
\hline & & 2018 & 92.9 & 100 & 100 \\
\hline \multirow{2}{*}{$\begin{array}{l}\text { Proclame Fit, WDG } \\
(400 \mathrm{~g} / \mathrm{kg}+50 \mathrm{~g} / \mathrm{kg})\end{array}$} & \multirow{2}{*}{0.14} & 2017 & 93.8 & 97.1 & 100 \\
\hline & & 2018 & 94.9 & 100 & 100 \\
\hline \multirow{3}{*}{$\begin{array}{c}\text { Proclame, WSG } \\
(50 \mathrm{~g} / \mathrm{kg})(\text { standard })\end{array}$} & \multirow{3}{*}{1.0} & 2017 & 85.9 & 85.7 & 96.6 \\
\hline & & 2018 & 99.0 & 100 & 100 \\
\hline & & 2019 & 100 & 100 & 94.1 \\
\hline
\end{tabular}




\section{Conclusion}

Therefore, in the studies carried out, it was found that new drugs, the active substances of which are metabolites of actinomycetes, have shown high efficiency in the control of economically significant pests of the grape spider mite and grape moth. According to the research results, the preparations Mekar, ME (18 g/l), Yunona, ME (50 g/l) and Proclame Fit, WDG $(400 \mathrm{~g} / \mathrm{kg}+50 \mathrm{~g} / \mathrm{kg})$ are included in the State Catalog of Pesticides and Agrochemicals Permitted for Use on the territory of the Russian Federation and can be used in biologized grape protection systems.

\section{References}

1. Milka Glavendekic, Tatiana Dolzhenko, Viktor Dolzhenko, Future IPM 3.0 towards a sustainable agriculture. IOBC-WPRS general assembly Meeting of the WGs Integrated protection in viticulture, Induced resistance in plants against insects and diseases and Multitrophic interactions in soil, Riva del Garda, Italy, 363-364 (2017)

2. Milka Glavendekic, Tatiana Dolzhenko, Natalia Beliakova, Viktor Dolzhenko Future IPM 3.0 towards a sustainable agriculture. IOBC-WPRS general assembly Meeting of the WGs Integrated protection in viticulture, Induced resistance in plants against insects and diseases and Multitrophic interactions in soil, Riva del Garda, Italy, 373-374 (2017)

3. T.V. Dolzhenlo, Agrochemical, 4, 34-40 (2017)

4. M.K. Dzhafarov, F.I. Vasilevich, M.N. Mirzaev, Agric. biology, 54(2), 199-215 (2019) https://doi.org/10.15389/agrobiology.2019.2.199eng

5. T.V. Dolzhenko, S.D. Karakotov, V.I. Dolzhenko, Russ. Agric. Sci., 44(6), 528-532 (2018) https://doi.org/10.3103/S1068367418060034

6. W.C. Campbell, Curr. Pharm. Biotechnol., 13(6), 853-865 (2012) https://doi.org/10.2174/138920112800399095

7. T. Lynagh, J.W. Lynch, Front. Mol. Neurosci., 5, 60 (2012) https://doi.org/10.3389/fnmol.2012.00060

8. M. Saber, Z. Ahmadi, G. Mahdavinia, Exp. Appl. Acarol., 1, 1-13 (2018)

9. I.S. Chen, M. Tateyama, Y. Fukata, M. Uesugi, Y. Kubo, J. Physiol., 595(17), 5895-5912 (2017) https://doi.org/10.1113/JP274871

10. S.-Y. Wang, Y.-H. Bo, X. Zhou, J.H. Chen, W.J. Li, J.P. Liang, G.Q. Xiao, Y.C. Wang, J. Liu, W. Hu, B.L. Jiang, BioMed. Research. Int., 2017, 5373262 (2017) https://doi.org/10.1155/2017/5373262

11. H.S. lper, J.L. Avalos, Synth. Syst. Biotechnol., 3(1), 1-2 (2018) https://doi.org/10.1016/j.synbio.2018.01.002

12. C.L. Bayly, V.G. Yadav, Molecules, 22(2), 235 https://doi.org/10.3390/molecules22020235

13. J. Guo, X. Zhang, X. Lu, W. Liu, Z. Chen, J. Li, L. Deng, Y. Wen, Front. Microbiol., 9, 1358 (2018) https://doi.org/10.3389/fmicb.2018.01358

14. D.E. Cane, J. Antibiot., 69(7), 473-485 (2016) https://doi.org/10.1038/ja.2016.55

15. A.J. Wolstenholme, M.J. Maclean, R. Coates, C.J. McCoy, B.J. Reaves, Invert. Neurosci., 16(3), 7 (2016) https://doi.org/10.1007/s10158-016-0190-7 